\title{
DNA Finger Printing and Horoscopy for Determining Paternity or Maternity of a Child
}

\author{
Y. V. Subba Rao ${ }^{1}$, Y. V. Ramana $\operatorname{Rao}^{2}$ \\ ${ }^{1}$ Dept. of Science, University Science and Instrumentation Centre (USIC), S. V. University, Tirupati, India \\ ${ }^{2}$ Dept. of Electronics and Communication Engineering, College of Engineering Anna University, Chennai, India
}

Email address:

yvsubbarao2004@yahoo.com (Y. V. S. Rao), yvrrao2011@gmail.com (Y. V. R. Rao)

To cite this article:

Y. V. Subba Rao, Y. V. Ramana Rao. DNA Finger Printing and Horoscopy for Determining Paternity or Maternity of a Child. Mathematics Letters. Vol. 3, No. 5, 2017, pp. 53-57. doi: 10.11648/j.ml.20170305.13

Received: March 9, 2017; Accepted: April 17, 2017; Published: October 31, 2017

\begin{abstract}
DNA finger printing technique of personal identification of an individual has been a boon in multitude of areas, chief of which as forensic evidence in crime investigation and matters of disputes of paternity and maternity cases. It is observed in horoscopy, that planetary configuration in the charts of parents and children is largely identical and corroborate with the findings of Michel Gauquelin in determining paternity or maternity of a child. This fact of the matter is examined and discussed in this paper and thus concluded that horoscopy can be used as supplementary evidence in determining paternity or maternity of a child.
\end{abstract}

Keywords: DNA Finger Printing, Horoscopy, Forensic Evidence, Planetary Configuration, DNA Analysis, Proteins in Hair

\section{Introduction}

The Human DNA (Deoxyribonucleic acid) consists of more than 3 billion base pairs of 4 different nucleic acids (nucleotides) that make up the genetic code of a human (Figure 1). This equals about 750 Megabytes of data that holds all instructions needed for the development of a complete living organism. It is therefore often referred to as a "blueprint" to construct all cells, organs, skin, hair, nails and other components (such as proteins and RNA) necessary for creating a functioning organism like our body. This genetic information is stored in segments of the DNA called "genes". This is the main purpose of DNA - the long-term storage of genetic information. The DNA contained in Human Embryonic Stem Cells can let them grow into every part of the human body such as heart, liver, kidney, brain, ears, eyes, bones or skin. As such, these cells are currently subject of intensive scientific research. The results could provide many new possibilities for therapeutically treatments for a whole range of diseases that are currently deemed incurable. The human genome is almost $99.9 \%$ identical between one person to the next. The difference $0.1 \%$ variation is the basis to distinguish one individual from another which fact is well utilised in forensic science $[1,2]$.

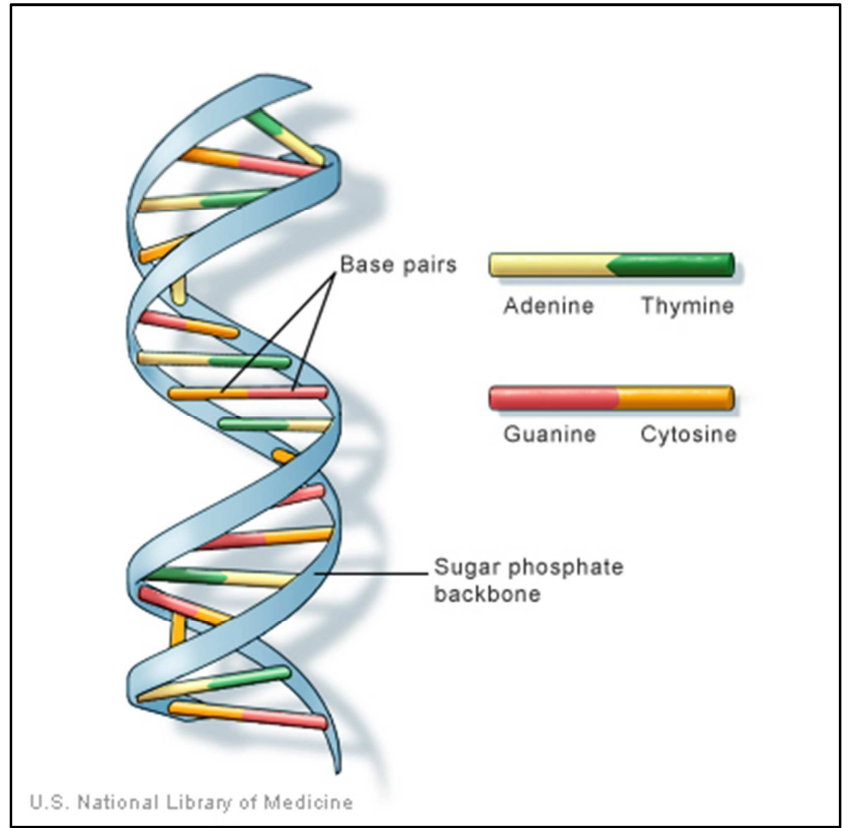

Credit: U.S. National Library of Medicine

Figure 1. DNA is a double helix formed by base pairs attached to a sugar-phosphate backbone. 


\section{DNA Applications}

As there are no two persons to a horoscope, or finger prints, or finger print of DNA, each human being is unique in his/her own way. The study of DNA in relation to Cosmos, and in turn to Vedic Astrology, may open new doors in understanding the planets' role in bringing about a particular event in life. The conventional fingerprint occurs only on the fingertips and can be altered by surgery whereas a DNA fingerprint is the same for every cell, tissue, and organ of a person. It cannot be altered by any known treatment just as fate that cannot be altered or thwarted. The most important use of the DNA fingerprinting is the personal identification. DNA finger printing is used in accurately recognizing the DNA of a person. Personal identification is the main tool in forensic science in crime investigation It is found useful in uncovering the inherited diseases. In addition to forensics, DNA has been used to unite families. Consequently, DNA fingerprinting is rapidly becoming the primary method for identifying and distinguishing among individual human beings. DNA fingerprinting is used in paternity testing while in some cases it may also be used to determine the identity of the mother. Michel Gauquelin, an astronomer and statistician established that the planetary configuration in the natal charts of parents and children, is identical. Gauquelin's studies, which showed striking planetary similarities in the birth charts of parents and their children, comprise the strongest scientific evidence in support of astrology to date. [3]. The author, therefore, feels that the horoscopic charts of parents and children serves as supplementary evidence in matters of dispute of 'paternity' or 'maternity' in a court of law.

DNA fingerprinting is useful in fighting fraud. Very recently, a research team has identified proteins in hair that can be used instead of DNA to identify individual humans. Proteins in human hair could uniquely identify the person at a Crime scene. It may even replace DNA sequencing in forensic investigations [4].

\section{DNA Entries to Differentiate Individuals}

Based on DNA considerations, any two individuals differ in about three million i.e., $3 \times 10^{6}$ bases. Therefore, there are more than three million differences between your genome and anyone else's.

A catalog of all sequence differences for the entire population, which is now about $7 \times 10^{10}$ ( 7 billion), would require $3 \times 10^{6} \times 7 \times 10^{10}=2.1 \times 10^{17}$ entries [5].

\section{Natal Chart and Its Navāmśa Chart to Differenciate Individuals}

To form an idea of the world of such individualistic natal charts, sufficient to accommodate the dead, the living, and those to be born, in short, to accommodate the entire human species from creation to destruction, we have only to solve a problem in mathematics. The planets occupy different places on the ecliptic at different points of time. They will be forming various permutations and combinations. Without going into the various sub-divisions of a sign consisting of 30 degrees, known as Daśavargas $[3,5,6]$, that is, without attempting any details, and limiting our attention only to the basic chart based on the primary division of the zodiac into the twelve signs, let us examine the possible number of birth charts. With regard to the Rising Sign alone, we have 12 different birth charts. The Sun, the Moon, Mars, Jupiter, and Saturn may occupy anyone of the 12 signs and therefore a chart with the Rising Sign and the said five planets in any of the twelve signs will result in $12^{6}$ different charts. Out of the Rāhu (Dragon's Head) and the Ketu (Dragon's Tail), we have to consider only the position of one of them, since they always occupy the opposite signs. So, with the Rāhu (Dragon's Head) and the Ketu (Dragon's Tail), we have $12^{7}$ charts. We have, then, to consider the remaining two planets, Mercury and Venus. We know that when the Sun occupies a particular sign, Mercury can occupy the same sign or the one before or the one after it. So, with Mercury we have $12^{7}$ x 3 charts. We also know that when the Sun occupies a sign, Venus can occupy the same sign or any of the two sings before or after it. So, with the Rising Sign and the nine planets, we have $12^{7}$ x 3 × $5=537,477,120$ charts. We may now form an idea as to the number of birth charts, if only the Navāmsa, or the division of each sign into nine parts, is introduced regarding the Rising Sign as well as the nine planets. And it must be remembered that this most popular division of a sign (out of the Daśavargas) should at least be attempted to confer a individualistic touch to a chart. It is thus clear that the number of charts with all their details do not lag the number of human beings on the face of the globe during a given period. With the nine planets and twelve Signs of the Zodiac with only the Rising Sign and with the degree of freedom of each Planet in any Sign of the Zodiac, the probable number of charts is $12^{7} \mathrm{x}$ $5 \times 3=12^{7} \times 15=537,477,120$. If the Navāmsa (one ninth of a Sign) is introduced regarding the Rising Sign and nine Planets, then the possible number of charts would be $(12 \times 9)^{7} \times(5 \times 9)$ $\mathrm{x}(3 \times 9)=108^{8} \times 11.25 \approx 2.1 \times 10^{17}[6]$.

\section{Life Building Blocks in Meteorites}

Astrobiology division of NASA reported the finding of life building blocks of DNA in meteorites [7] (Figure 2). Jennifer $\mathrm{G}$. Blank and his team of researchers reported that the amino acids were intact despite huge combustion temperature and enormous impact of collision of meteorites with the earth [8]. The interplanetary transportation of meteorites [9] also corroborates with the truth of Hindu philosophy [10]. It is tradition among Indians that those, while living on the Earth, who perform meritorious deeds go to Heaven upon death. One who is promoted to one of those higher planetary systems (urdhva lokas) with an astral body enjoys a longer duration of life and better facilities for sense enjoyment, yet one is not allowed to stay there forever and is sent back to this earthly planet to be reborn upon finishing the resultant fruits of pious activities in the higher realms with $[11,12]$. Earth (Bhuloka) is 
the lowest of the seven higher lokas where human beings exist in physical form in the whole universe.

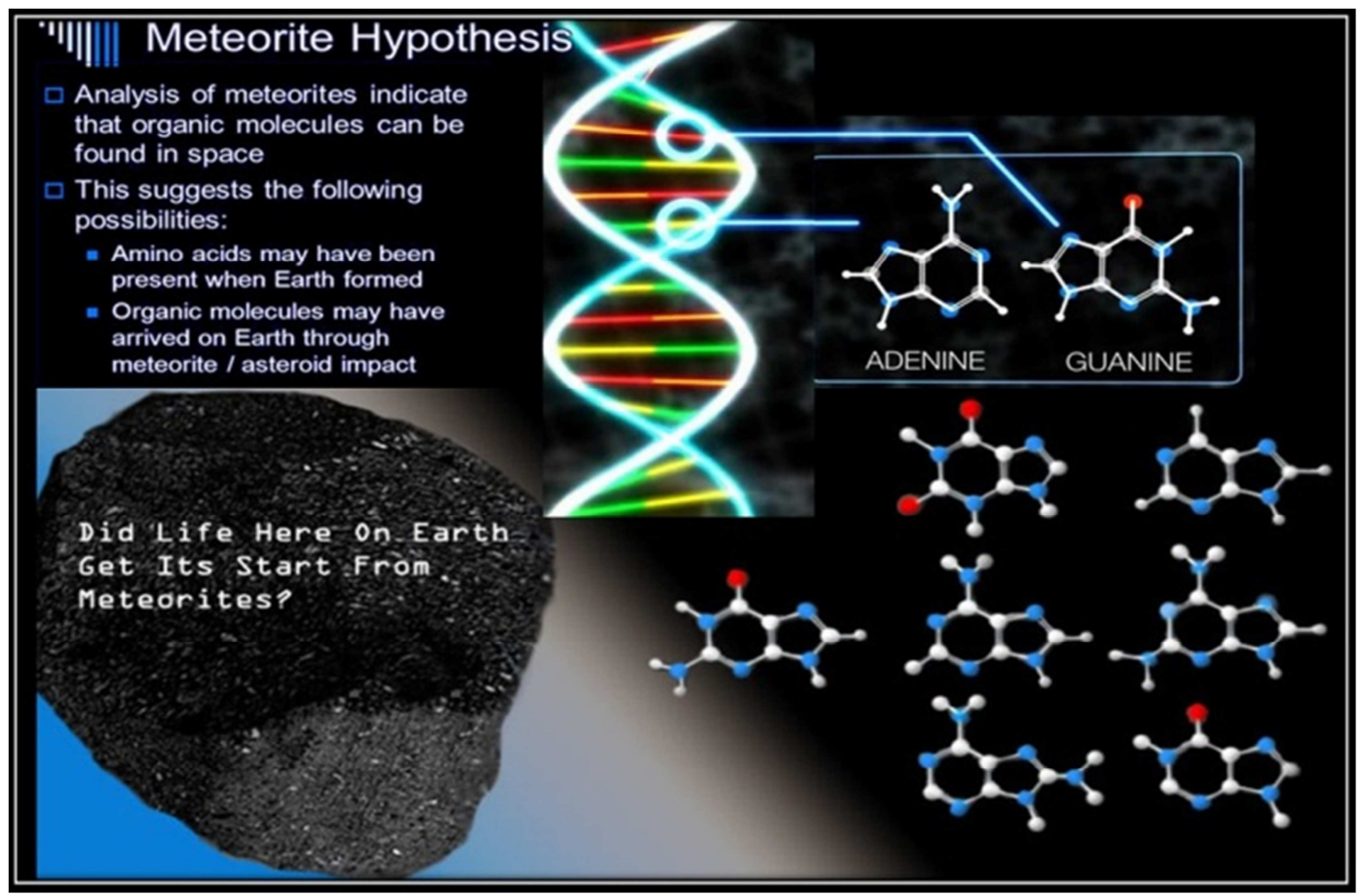

Figure 2. Meteorite containing Guanine and Adenine (Courtesy: NASA).

\section{Correlation of Mass of Planets and Molecular Weights of DNA}

Hydrogen, the first element that surfaced immediately after Big Bang, is found in the Sun, the centre of our solar system, in thalamus, the centre of Human Basal ganglia nuclei, and in the central strands of human DNA (Deoxyribonucleic Acid) is the apparent basis of terrestrial life [13]. It is therefore reasonable to correlate the planets of our solar system as cosmic counterparts with human DNA. So, the Hydrogen Bonds represent the Sun, whose composition is 92 per cent
Hydrogen, and around which all the planets move. Similarly, the various components of DNA based on their molecular weights relate to the different planets in the Solar System based on their mass. Guanine, the heaviest constituent of DNA to the heaviest planet, Jupiter; likewise, Adenine corresponds to Saturn, Cytosine to Mars and Thymine to Venus. Sugar corresponds to Moon as Moon signifies all white substances such as milk, salt, sugar etc., Phosphate corresponds to Mercury as Mercury signifies all chemical substances, and enzymes which act within the DNA correspond to Ascending and Descending Nodes of the Moon [14] These relationships are shown in Table 1.

Table 1. Correlation of Mass of Planets and Molecular Weights of DNA Bases.

\begin{tabular}{lllll}
\hline Sl. No. & DNA Component & Molecular Weight & Cosmic Counterpart & Mass (Earth's Mass=1) \\
\hline 1 & Guanine & 149 & Jupiter & 317.80 \\
2 & Adenine & 135 & Saturn & 95.20 \\
3 & Thymine & 125 & Venus & 0.82 \\
4 & Cytosine & 110 & Mars & 0.12 \\
5 & Phosphate Molecule $\mathrm{PO}_{4}$ & ---- & Mercury & 0.05 \\
6 & Sugar Molecule & ---- & Moon & 0.123 \\
7 & Hydrogen (Nucleus) & ---- & Sun & ---- \\
8 & Coenzymes & ---- & North and South Lunar Nodes & ----- \\
\hline
\end{tabular}

Hence, it is reasonable to associate the dna molecules to the planets of our solar system and that dna molecules are available as readymade kits in space and transported by meteorites from space to earth and from earth to space.

\section{Horoscopy in Forensic Science}

Michel Gauquelin's Planetary Heredity Tests of planetary links between parents and children seemed positive. He demonstrates that we were born under similar cosmic conditions as prevailed at the birth of our parents and graphs a relationship between human heredity and the stars., chart 1 of the father and chart 2 that of the son.

Every family member is linked with each other from certain astrological figure. In my own family, my father and I do have many planets positioned exactly in the same signs of Tropical Zodiac and have similar significant characteristics of life. (Figure 3: Charts $1 \& 2$ ) 


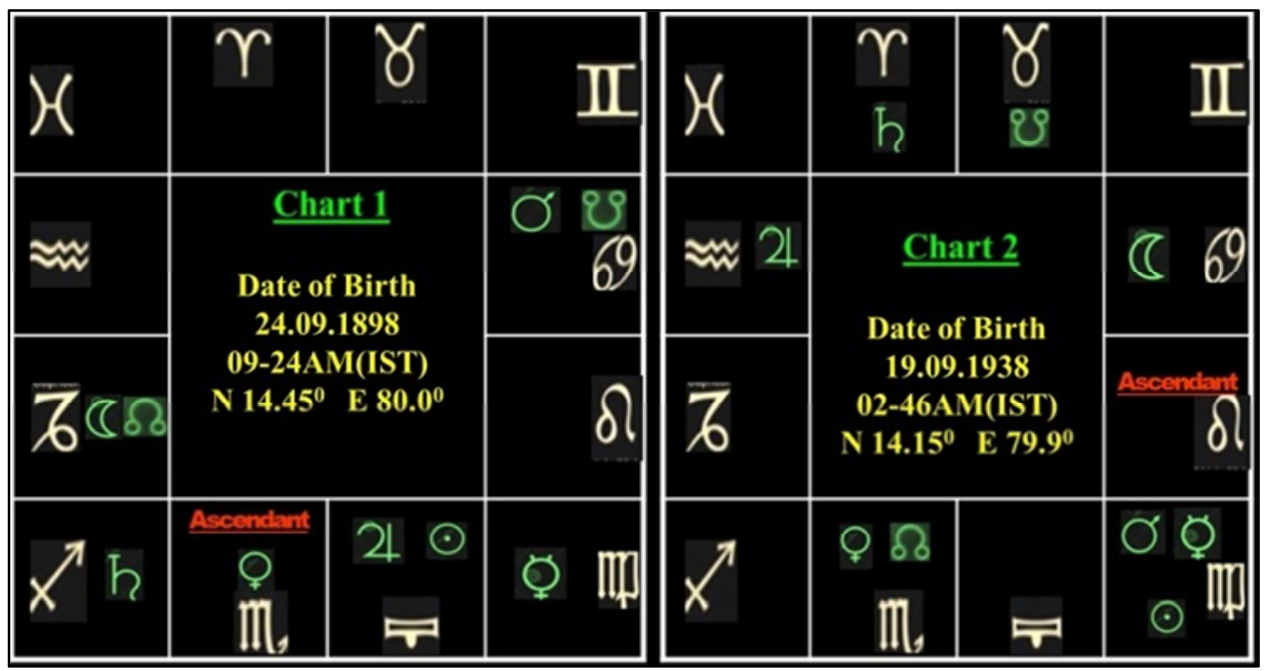

Figure 3. Tropical Charts 1 and 2.

The following Table clearly describes the planetary configurations in the above two tropical charts belong to the father and son, and their salient significations. From the Table, it is clear the heredity of planets works. This work may not be decisive but can be conclusive Forensic evidence in matters of disputes between different families claiming a child as their own in a court of law.

Table 2. Description of Charts 1 and 2.

\begin{tabular}{|c|c|c|c|c|}
\hline Sl. No. & Planet & $\begin{array}{l}\text { Position of Planets in } \\
\text { Chart } 1\end{array}$ & $\begin{array}{l}\text { Position of Planets } \\
\text { in Chart } 2\end{array}$ & Remarks \\
\hline 1 & Mercury & $\begin{array}{l}\text { Virgo Mercury } \\
\text { (Exalted) }\end{array}$ & $\begin{array}{l}\text { Virgo Mercury } \\
\text { (Exalted) }\end{array}$ & $\begin{array}{l}\text { Mercury Exalted in both Charts. Native of Chart } 1 \text { authored } 7 \text { Monographs on } \\
\text { Evidence Act. Native of Chart } 2 \text { authored } 10 \text { Books on Modern Science in Vedas. }\end{array}$ \\
\hline 2 & Venus & Scorpio & Scorpio & In the same Sign in both the charts and both have the same curly hair style. \\
\hline 3 & Sun & Libra & Virgo & They are in conjunction, difference being $6^{0}$ only \\
\hline 4 & Moon & Capricorn & Cancer & They are in Opposition \\
\hline 5 & Mars & $\begin{array}{l}\text { Cancer Mars } \\
\text { (Debilitated) }\end{array}$ & Virgo & $\begin{array}{l}\text { In Chart } 1,6^{\text {th }} \text { Lord Mars from the Ascendant is debilitated in the } 9^{\text {th }} \text { House and } \\
\text { aspected by } 9^{\text {th }} \text { Lord Moon }\end{array}$ \\
\hline 6 & Jupiter & Libra & Aquarius & $\begin{array}{l}\text { The placement of Jupiter in } 1^{\text {st }} \text { and } 2^{\text {nd }} \text { Charts are in Square. Native of Chart } 1 \text { is an } \\
\text { Advocate and Native of Chart } 2 \text { is a faculty member in a University. }\end{array}$ \\
\hline 7 & Saturn & Sagittarius & $\begin{array}{l}\text { Aries } \\
\text { Saturn (Debilitated) }\end{array}$ & The placement of Saturn in $1^{\text {st }}$ and $2^{\text {nd }}$ Charts are in Square \\
\hline 8 & Saturn & Sagittarius & $\begin{array}{l}\text { Aries Saturn } \\
\text { (Debilitated) }\end{array}$ & $\begin{array}{l}\text { In Chart } 2,6^{\text {th }} \text { Lord Saturn from the Ascendant is debilitated in the } 9^{\text {th }} \text { House and } \\
\text { aspected by } 9^{\text {th }} \text { Lord Mars }\end{array}$ \\
\hline
\end{tabular}

\section{Conclusion}

This leads us to a plausible conclusion that magnetism of a planet in the same sign in respect of individuals have some similar effect and character in heredity. Protein, from hair and planetary configuration in tropical charts of parents and children may join DNA finger printing in human identification and in matters of dispute relating maternity or paternity of a child and corroborate with the findings of French statistician and scientist Michel Gauquelin's work, in which human biological clocks keep time with the planets.

\section{References}

[1] Rao, Y. V. S, (Nov 2014), Natal Charts vis-a-vis DNA Entries Journal of Advances in Philosophy Online Journal www.cirworld.com, Vol. No.1, Page 14-19.

[2] Thomson Gate 2005, Genetics and Genetic Engineering, www.encyclopedia.com

[3] Michel Gauquelin, Planetary Heredity, San Diego, CA: ACS Publications, 1988. Text ISBN 10: 0935127011/ ISBN 13: 9780935127010 .

[4] journal PLOS One, 2016 September, www.popsci.com/how-protein-in-your-hair-is-better-at-identif ying-you-than-dna

[5] J. Craig Venter Institute, Genomes, Online publication, Jan, 2003. John Mersch, Medicine Net.com.

[6] Rao, Y. H. and Rao Y. V. S, Astrology on the Moving ZodiacThe One system for the East and the West, 2004.

[7] Callahan, (Aug 9, 2011), DNA Blocks found in Meteorites, Proceedings of the National Academy of Sciences of the United States of America.

[8] Jennifer G. Blank, 2012, 243rd National Meeting \& Exposition of the American Chemical Society (ACS).

[9] An Inter-Planetary Shuttle? (Jul 25, 2013) www.dailygalaxy.com 
57 Y. V. Subba Rao and Y. V. Ramana Rao: DNA Finger Printing and Horoscopy for Determining Paternity or Maternity of a Child

[10] www.sanskritweb.net/sansdocs/gita-big.pdf page 11 Chapter 9 Text 21. The Devanagari text was typeset in 24 point "Sanskrit 2003" on 32-point body.

[11] hinduwebsite.com/sacredscripts/hinduism/upanishads/chandog ya.asp

[12] Max Müller, F, Fourth Brâhmana in Brihadaranyaka Upanishad, Fourth Brahmana. Translated by as The Upanishads, Part 2 (SBE15) Life Comes from Life - written by A. C. Bhaktivedanta Swami Prabhupada (founder of ISKCON).
[13] Rao, Y. V. S, Man is a Microcosm of the Macrocosm, the Universe, 2013, Journal of Advances in Philosophy (Council of Innovative Research Publications) Vol.1, No 1: JAPY page 27-47.

[14] Tony Nader, (2000), Human Physiology, Expression of Veda and the Vedic Literature, publ: Maharshi Vedic University. 